\title{
Race, Resistance and Translation: the case of John Buchan's UPrester John
}

Hermann Wittenberg

\begin{abstract}
:
In postcolonial translation studies, increasing attention is being given to the asymmetrical relationships between dominant and indigenous languages. This paper argues that John Francis Cele's UPrester John (1958), is not simply a subordinated and obeisant translation of John Buchan's adventure thriller Prester John (1910), but a more complex form of textuality that is both oppositional and complicit with the workings of apartheid. Although Cele's translation reproduces Buchan's story of a daring young Scotsman who singlehandedly quells a black nationalist uprising, it also ameliorates the novel's racist language and assumption. Cele's translation practice is examined in the context of apartheid publishing and Bantu education.
\end{abstract}

Keywords: John Buchan, Prester John, John Francis Cele, translation, Bantu education, Zulu literature, resistance, race

\section{Theories of Postcolonial Translation}

In postcolonial studies, the textual and political practices of translation have gained growing notice, focusing renewed attention on how the semiotic seam between Western and various non-metropolitan and postcolonial cultures is continuously constructed and re-constituted through multiple acts of translation. Judging from the geo-political distribution of key scholars working in new translation studies - South America, India, Australia - the cultural and political legacy of empire is particularly significant, shifting the field of formal translation studies from its positivist base in general linguistics to the broader interdisciplinary area of cultural studies.

Translation studies is thus increasingly less narrowly focused on processes of textual transcription and code comparative work. Translation (and equally crucially, mis-translation) is central to the complex workings of cultural change and identity formation, whether in the form of the formal transcription of texts from one language to another, or in the more extended sense of multiple negotiations of meaning in the transcultural realities of the everyday. As Homi Bhabha has put it, "we should remember that it is in the 'inter' - the cutting edge of translation and negotiation, the in-between space - that carries the burden of the meaning of culture" (1994: 38). 
The editors of a volume of essays on postcolonial translation argue that "translation has always been at the heart of the colonial encounter" (Bassnett \& Trivedi, 1999, 17). Or as Vicente Rafael has more recently pointed out, "translation historically has served as an instrument of domination under colonial rule" (2007: 214). Tejeswini Niranjana's study of Indian pre-colonial ancient texts translated into English, for example, finds that in "creating coherent and transparent texts and subjects, translation participates in the fixing of colonized cultures, making them seem static and unchanging rather than historically constructed" (1992: 2). Similarly, Anuradha Dingwaney and Carol Maier have argued that:

the process of translation involved in making another culture comprehensible entails varying degrees of violence; ... alien cultural forms or concepts or indigenous practices are recuperated (translated) via processes of familiarization whereby they are denuded of their 'foreignness'. (1995: 4-6)

Dingwaney and Maier view translation as a violent process through which colonial powers translate foreign texts into their own language on their own terms, thus eradicating cultural difference and creating a buffer zone of assimiliated sameness. This notion is founded on the influential work of the translation theorist Lawrence Venuti, who distinguishes between two types of translation strategy: domestication and foreignization. The former, as described above by Niranjana, and Dingwaney and Maier, has dominated in AngloAmerican translation culture and involves "an ethnocentric reduction of the foreign text to ... target language cultural values" (Venuti 1995: 20). Domesticating translations read easily by smoothing out difference and toning down strangeness, and Venuti proposes the ideal of a foreignizing translation practice that still leaves the linguistic, stylistic and cultural otherness intact.

In his volume Translation and Empire (1997), Douglas Robinson pursues a similar analysis where translation is primarily regarded as "a channel of colonization, parallel to and connected with education and the overt or covert control of markets and institutions"; or, conversely in the aftermath of the empire writing back, as "a channel of decolonization" (1997:31). Richard Jacquemond, in his study of French-Arabic translations, sees a similar historical dynamic. During the phase of the "colonial moment" native translators working in the dominant culture are "servile mediators who integrate foreign objects without question" (1992: 157) and collaborate in producing Orientalist knowledge, until, during the postcolonial moment, a more questioning mode is employed, subverting the idea of Europe as the original, with the colonies being lesser copies.

\section{https://repository.uwc.ac.za/}


In understanding colonial acts of translation as essentially violent discursive appropriations of third world cultural and social experience, these postcolonial approaches invite a re-interpretation of the imperial archive. But despite this revisionist and radical stance, this argument is also in danger of simplifying the complexities of colonial translation as textualised hegemonic relations between an oppressive Western interpretive regime, and a misunderstood and mistranslated indigenous culture. The postcolonial model of translation also relies on the conventional dualisms long established in the discipline, going back as far as Friedrich Schleiermacher's (1813) distinction between the linguistic "word-for-word" and the literary "sense-for-sense" translation. Even Venuti's opposition between 'foreignizing' and 'domesticating' translation proposes a perhaps too neat distinction between these two modes of translation and such binarisms are not necessarily useful in providing satisfactorily models when studying colonial translation, where the practice of translation needs to be located in the larger coercive cultural politics of empire. As Else Viera has put it, translation, as a cultural practice, always "disturbs linear flows and power hierarchies, and unsettles the logocentrism of the original" (qtd in Bassnett \& Trivedi 1999:15), a process that Gayatri Spivak, in an essay titled "The Politics of Translation", refers to as "disruptive rhetoricity" (2000: 398).

\section{Prester John and Empire}

In order to test some of the ideas discussed in the above brief overview of the theoretical terrain, I want to focus on a very specific, local translation situation, reporting on a process of reverse-translation or back-translation that will allow us to reflect on current ideas in postcolonial translation studies as well as explore a lesser known aspect of South African literary history. The case study presented here is, however, less an example of colonial servility, nor is it a rewriting of European master discourses in a counter-hegemonic manner, but a more complex form of textuality that is both oppositional and complicit with the workings of colonialism.

The text in question here is a classic colonial adventure romance, namely John Buchan's Prester John, written in 1910. In his time, Buchan was one of Britain's most celebrated writers and politicians, and he must rank among the most prolific and widely read English authors of the 2oth century. With the hugely popular Thirty-Nine Steps (1915) Buchan is generally credited with inventing the genre of the spy-thriller, and altogether he wrote more than a hundred other books, among them historical novels, imperial romances, adventure thrillers, travel narratives and volumes of short stories. Besides his literary efforts, he produced a vast output of journalism and historical writing. Although Buchan

\section{https://repository.uwc.ac.za/}


had a remarkable political career in which he reached one of the highest political offices in the Commonwealth as the Governor-General of Canada, was the confidante of royalty and had the ear of presidents, even becoming the first Briton to address the United States Congress, he is not primarily remembered as a politician, but as the author of popular "shockers", especially the Hannay thrillers. Buchan's dual career as both an imperial politician and a writer of imaginative fiction makes him an exemplary instance of what Bruce McLeod has called a "strategic writer" whose work is "relational to, situated, and invested in the flows of knowledge, power, and opposition that course through the capillaries of Britain's empire" (1999:16).

Buchan wrote Prester John after serving briefly in Britain's new imperial administration in the defeated Transvaal republic after the Anglo-Boer War. The novel deals with the problem of colonial white settlement in Africa, and can be read as an attempt to confront settler fears of a black revolt against white rule imaginatively. Such fears were not without foundation in the aftermath of the war in which the Boers and British had bitterly fought each other. In this volatile context of perceived white disunity and weakness, there were several minor black uprisings, most notably in 1904 and 1906, and it is likely that these provided the background material for Buchan's imagination, as argued by Tim Couzens (1981: 1-24).

With its breathless action, narrow escapes and upright morals, Prester John is a racy adventure thriller of the type that has fascinated British schoolboys for generations. The story revolves around a young Scottish trader, David Crawfurd, who saves white South Africa single-handedly from a secret black uprising with daring adventure and courage, making himself a fortune in gold and diamonds. The action of the novel is built around the conventional opposition between a white hero (Crawfurd) and a black villain (Laputa), but this structure is significantly complicated by a powerful and dangerous identification between Crawfurd and Laputa, the charismatic leader of the uprising. Indeed, at the end of the novel, Laputa, "the last of the kings of Africa" (1975: 221) has died heroically, quoting Shakespeare. Overall, though, the novel does not only celebrate the defeat of the uprising and the reassertion of supreme white rule over black Africans, but is also shot through with racist language including offensive words such as "kaffir" and "nigger". Many of the racist assertions about the "Kaffir rising" and supposed innate black inferiority are difficult to stomach today, but we should also remember that Buchan wrote at a time less constrained than ours by the imperatives of political correctness. Furthermore, it is also worth noting that Buchan's thinking about imperialism and race was far more moderate

\section{https://repository.uwc.ac.za/}


and enlightened than that of many of his contemporaries, and in the figure of Laputa he created an extraordinarily hybrid character.

The problematic nature of the text has however not hindered its broad popular appeal, first in serialised format and then in successive book editions with reprints being issued well into the 1990s. Until the 1970s Prester John was a popular school text book in Britain and was widely prescribed in the Commonwealth, fitting well into a cultural milieu shaped by Rider Haggard, Treasure Island and the Boy Scouts. There have nevertheless been reports of deviant or anti-colonial readings, for example the anecdote that Jomo Kenyatta read Prester John in prison as a study in resistance strategy (Schwartz, 1997:123). But mostly readers, even black readers, imbibed the colonial subtext. On his childhood reading of Prester John, Chinua Achebe for example writes:

I did not see myself as an African to begin with. I took sides with the white men against the savages. In other words, I went through my first level of schooling thinking I was of the party of the white man in his hair-raising adventures and narrow escapes. The white man was good and reasonable and intelligent and courageous. The savages arrayed against him were sinister and stupid or, at the most, cunning. I hated their guts. (qtd in Schwartz, 1997:123)

Achebe's comments about Prester John are a revealing insight into the way in which colonial schooling was successful in shaping the attitudes and ideas of Africans. Positioned by the structure and force of the narrative, the colonial child assumes the ideology of the colonial master, precisely that process that Ngugi wa Thiongo, in Decolonising the Mind, has liked to a "cultural bomb" (1986:3).

\section{John Francis Cele and Bantu Education}

Let us now see how these arguments apply to the specific case of John Francis Cele's translation of Buchan's text into Zulu, published in 1958 as UPrester John. Little is known about Cele. He was born in 1897 at Nhlungwane in the Mahlabathini district in the then colony of Natal and was trained at the St Chad's mission college to become a teacher. In 1948 he published a well-regarded Zulu grammar titled Nasi-ke IsiZulu (meaning "So this is Zulu") which enjoyed considerable success as a school textbook for many decades. Apart from UPrester John, Cele also translated another colonial romance, namely Rider Haggard's King Solomon's Mines under the title Imigodi YeNkosi USolomon (1956). After teaching in various schools in the northern parts of Kwa Zulu Natal, Cele left the profession to become a personnel officer at the Hlobane coal mine (Ntuli 2006).

\section{https://repository.uwc.ac.za/}


Cele's career as teacher and translator must be understood within the broader context of first colonial and then apartheid education. In colonial South Africa, the education of Africans and the publication of texts in the vernacular were mostly a concern of missionaries, not the state. The Lovedale Mission, established in 1823 in the Eastern Cape, ran a thriving press that printed Xhosa Bible translations, religious readers and other educational material that was deemed compatible with the larger civilising mission. The publication of Tiyo Soga's translation of Pilgrim's Progress in1867 made it the first novel printed in an African language. As several scholars, among them Isabel Hofmeyr (2003) and Phaswane Mpe (2000) have shown, however, African writers were constrained by the missionary agenda, which suppressed the carnivalesque aspect of indigenous cultures, as well as an overt political critique. The unequal relationship between African writers and their publishers, established in the various mission presses, provided the model for later apartheid publishing.

In 1953, the apartheid government promulgated the infamous Bantu Education Act which severely curtailed the educational role of the mission schools. The schooling was now to be directly controlled by the state, and black South Africans were to be taught only in their mother tongue, and no longer in English. According to the Commission on Native Education, no more English or Afrikaans should be taught than necessary "to follow oral or written instructions and to carry on a simple conversation with Europeans about his work and other subjects of common interest" (Gerard 1981: 207). According to one commentator, the act tried on the one hand to "achieve a definite lowering of educational standards by confining the black child to the limits of his tribal outlook, on the other hand, a fast growing market was created, almost overnight, for vernacular literary productions" (Gerard 1981: 207). The National Party government established language boards that drew up lists of suitable books to be prescribed in schools. By severely limiting and circumscribing the subject matter of African language books, most of the progressive writing published by mission presses by that time had no market any longer, creating the space for the emergence of Afrikanerowned publishing houses that were willing to supply ideologically compliant text books for the state - and reap handsome profits. The chief financial beneficiaries of apartheid education were thus the government-aligned publishing corporations such as Nasionale Pers (Naspers), which also published the party's mouthpiece daily Die Burger. The other giant Afrikaner publishing house was Perskor, which also published Die Transvaaler newspaper, at one time edited by H.F. Verwoerd. One of its educational divisions, Afrikaanse Pers, was responsible for publishing UPrester John. On its imprint it styled itself, without irony, as "The Bantu's Publishing Home."

\section{https://repository.uwc.ac.za/}


In evaluating the translation practices that emerged during "bantu education", it is useful to consider Richard Jacquemond's propositions about the asymmetrical nature of colonial translation. He suggests that a "dominated culture will invariably translate far more of a hegemonic culture than the latter will of the former", usually in order of $1-2$ percent of works translated, and that when a hegemonic culture does translate works produced by the dominated culture, those works will be perceived and presented as difficult, mysterious, inscrutable, esoteric and in need of a small cadre of intellectuals to interpret them, while a dominated culture will translate a hegemonic culture's works accessibly for the masses (quoted from Robinson's summary, 1999: 197).

Jacquemond's first point about the differences in numbers of translated books is obvious in that far more English (and Afrikaans) works were translated into Zulu (and other African languages) than vice versa. This is not surprising given that Zulu is a language with a strong oral tradition and only a marginal print culture, though Jacquemond suggests that this imbalance even exists where the dominated culture has a deeply entrenched literary tradition, such as Arabic. The second point is more interesting since it relates to the question of the quality rather than quantity of translated works. Jacquemond argues that the texts translated from the dominant culture should have a "mass appeal" amongst the readers of the dominated culture, an argument which in this case needs to be amended: despite its South African setting and plot that revolved around a black uprising against white rule, UPrester John was unlikely to have a broad, willing mass readership among Zulu speakers, unless this readership was artificially constituted and enforced through the "prescribed books" system of the education bureaucracy. It is rather more likely that education officials selected UPrester John for translation because it could be used as an exemplary text demonstrating the futility of black resistance. Like Achebe's experience of reading Buchan's novel as a child, as referred to earlier, young Zulu children were expected to imbibe the racialised message of white mastery over Africa.

While UPrester John clearly filled the demand for ideologically compliant vernacular books for the mass educational market, it is important to evaluate Cele's translation in the context of the National Party's ruthless implementation of apartheid education. Before branding Cele, a black Zulu teacher in the employ of the state, as a willing collaborator in apartheid education, one has to remember that options for dissent were strictly limited for black professionals in the 1950s, especially for those in state employ. As is evident looking at the coercive context of bantu education (see Kallaway 2002), it would have been impossible for Cele to produce a text that overtly challenged the racist ideologies of the day and also pass scrutiny of the educational authorities. Little research is available on the

\section{https://repository.uwc.ac.za/}


educational policy context of vernacular text books. As Alta Engelbrecht has shown in a survey article titled "Textbooks in South Africa from Apartheid to Post-Apartheid", most research on ideological bias has been limited to a critique of History and Afrikaans language textbooks, with no consideration given as yet to the translation practices associated with the production of vernacular language reading lists. Nevertheless, it is clear that the under-researched area of vernacular language materials also need to be considered when evaluating the impact of Bantu education ideology on black children.

South African history is largely a narrative punctuated by spectacular resistance to colonial violence and apartheid; the more subtle textual forms of black dissent are less visible. Yet, as will be seen, Cele's translation was a complex form of negotiation that is not easy to categorise as either resistance or collaboration. Instead, a form of story-telling emerges that valorises the humanness of experience, instead of relying on the binary stereotypes of racial classification. Cele can of course not change the essential Buchan storyline in which a black revolt is crushed, but I will argue that in the presentation of characters and events there is a nuanced and subtle shift in the colonial perspective.

\section{UPrester John}

In order to examine the nature of Cele's translation, the following methodology was used. Cele's Zulu text was translated back into English by a Zulu speaking student research assistant who was not familiar with the Buchan original. The two English versions, the one by John Buchan and the new one by Ms Anda Nombexana were then compared. A word of caution is necessary here: firstly, I am not a Zulu speaker, secondly, for my research assistant English is very much a second language. Furthermore Cele's Zulu is of the pure or "deep" variety, an archaic form that is not often readily understood by modern speakers of the language. All these factors have invariably contributed to less than perfect translations and analysis, though the examples cited below were cross-checked by a Zulu-speaking colleague Despite these constraints, a number of clear trends and findings have emerged.

Firstly and most obviously, Cele's abridged version of Buchan's novel leaves out the offensive racial language of the original. Statements such are the following in Buchan's original are simply omitted:

"He had none of the squat and preposterous Negro lineaments, but a hawk nose like an Arab, dark flashing eyes, and a cruel and resolute mouth." (25)

\section{https://repository.uwc.ac.za/}


"Hang it all, what are we coming to, when we are turning into a blooming cargo-boat for niggers" (29)

'I felt that was being hemmed in by barbarism, and cut off from my own kind in a ghoulish land from the succour of my own kind" (63)

Similarly, all obeisant forms of servile language with which black people were expected to address whites are left out:

"This is your room, Baas" (34)

Also left out is an extended discussion about the reasons for and prospects of the black uprising, especially details of white fears that under apartheid could be viewed as provocation or incitement:

My houseboy might be in the rising, and I would never suspect it till one fine morning he cut my throat. 58

Conversely however, Cele also leaves out the fiery anti-white speech that Laputa makes upon assuming the leadership of the rebellion:

What have ye gained from the white man? ... Ye, the old masters of the land are now servants of the oppressor. And yet the oppressors are few and the fear of you is in their hearts. 114

One can assume that books with such potentially incendiary ideas as above would not have been found appropriate for black students by the apartheid education authorities, and Cele was either censored or was censoring himself.

When not leaving out parts of Buchan's novel that would be offensive to black readers, Cele modified the language subtly, in such a way as to moderate its offensiveness. Some examples follow (JB refers to John Buchan's original text, JFC to Cele's version, AN to the retranslated text):

JB: Native children played in the dust, and an old Kaffir squatted by the wall. 34

JFC: Laphaya ebhuqwini kudlala izingane zabantu abakhelene nesitolo, kuhlezi khona lapho umuntu omnyama omdala encike ngodona. 12 
AN:There in the dusty soil there were children of the people who live nearby the store who are playing, next to them was an old black person who was sitting next to the wall.

Both the offensive words "native" and "kaffir" are changed: "native" is replaced by the circumlocution "of the people who live nearby the store" and the deeply offensive other word is replaced by the respectful word "person" (umuntu), qualified by the adjective "black" (omnyama) which has no pejorative racial connotations.

Sometimes, Cele's translation makes subtle but significant changes, as we can see in the following example:

JB: Blauwildebeestfontein had no more than two buildings of civilised shape. 33

JFC: Laphaya ekupphelweni kwethala kwakhe izindlu ezedlule kwezimbili zesimanje. 12

AN: $\quad$ There at the end of the road there were two houses built in a modern way.

In Buchan's text, the "two buildings of civilised shape" referred to the European dwellings, which were rectangular in design, as opposed to the traditional round huts of Africans. The association between whiteness and civilisation, and conversely between blackness and barbarism is almost unnoticeably defused in Cele's translation: the European buildings are simply described as "modern" as opposed to traditional.

Cele's respectful treatment of characters in the novel even extends to minor European figures, such as Crawfurd's boss Colles, whose fatness does not find its way into the Zulu version:

JB: He was a certain Mr Colles, a big fat man, who welcomed me in his shirtsleeves, with a cigar in his mouth. He received me pleasantly, and took me home to dinner with him. 27

JFC: KwakunguMnu. Colles, umfo ojahele ngemplea, owangibingelela efingqe imikhono, eshunqisa usiganzi. Wangemukela ngentokozo, wangiyisa ekhaya eyonginika okwasethunjini. 10 
AN:Mr Colles, was in haste in his rolled up shirt while he was smoking, he warmly welcomed me and took me to his home for something to eat.

In much of his translation, Cele domesticates the foreign text, substituting place names and idioms with Zulu versions. The locus of much of the novel's action, namely the village of Blauwildebeestfontein is translated as "Spring of Inkonkoni”, and figurative Zulu expressions and idioms frequently enter the text, for example when the phrase "he regarded me with deadly hatred" (1975:56) is translated as "he hated me like a snake".

\section{Conclusion}

It is evident that the translation of English fiction such as Prester John fitted into the broader ideological agenda of apartheid education, but the role that translated literary texts played in the construction of the "bantu education" edifice clearly needs far more comprehensive investigation. This findings of this analysis may well be typical for the whole range of translated texts and their translators, but this would need a more large-scale and in-depth study of the various text books, together with the curricula, the prescribed book lists and records of the language boards across the various African languages over a number of years.

The findings in this analysis are however compatible with Jacobus Naude's research into the translations of English novels into Xhosa, for example his analysis of J.R.R. Jolobe's Imigodi kaKumkani uSolomon (1968), a translated version of Rider Haggard's King Solomon's Mines, a novel that Cele had also translated into Zulu. Naude similarly finds that:

"the strategies employed by Jolobe provide an example of the trends followed by translators of colonial texts to cushion their harsh imperialistic overtones in order to make them palatable and appropriate for the culture of the target readership" (Danso and Naude 2004: 131).

Their assertion, namely that such texts "play an important role in the enrichment of the receiving culture" (2004: 121) is however arguable, and would not seem to be applicable in the case of Cele's work.

In conclusion then, Cele's translation of Prester John shows that colonial translation practice is not necessarily simply a case of coercive oppression and co-option. Douglas Robinson's characterisation of such translation as simply "a channel of colonisation, parallel to and connected with education and the overt or

\section{https://repository.uwc.ac.za/}


covert control of markets and institutions" (1997: 31) is clearly not an adequate analysis of the more complex situation under apartheid. Similarly, Richard Jacquemond's distinction between the "colonial moment" where translators are "servile mediators" who integrate foreign objects without question, and the "postcolonial moment" where the dominating culture is rejected (1992:157) is also not appropriate. Cele's translation of a paradigmatic colonial text rather shows that even under coercive and oppressive conditions, translation remains a subtle language game in the arts of the possible where the demands of a repressive regime are carefully balanced with the imperatives of humane storytelling. 


\section{References}

Bassnett, S.and H. Trivedi. 'Introduction'. Postcolonial translation: theory and practice. Eds S. Bassnett and H. Trivedi. London: Routledge, 1999, 2-7.

Bhabha, Homi K. The Location of Culture. London: Routledge, 1994.

Buchan, John. Prester John. London: Pan Books, 1975 (1910).

Buchan, John. UPrester John. Trans. J.F. Cele. Johannesburg: Afrikaanse Press, 1958.

Couzens, Tim. 1981. “The Old Africa of a Boy's Dream” - Towards interpreting Buchan's "Prester John"'. English Studies in Africa. 24/1, 1981:1-24.

Danso, $\mathrm{N}$ and J. Naude. 'Trends in colonial translation. Henry Rider Haggard's "King Solomon Mines" in Xhosa'. Journal for Semitics 13/1, 2004: 121-132.

Dingwaney, Anuradha and Carol Maier. Between Languages and Cultures. Translation and Cross-cultural Texts. Pittsburgh and London, University of Pittburgh, 1995.

Engelbrecht, A. "Textbooks in South Africa from Apartheid to post-Apartheid: Ideological change revealed by racial stereotyping”, 2006. Accessed 1 November2010, from http://info.worldbank.org/etools/docs/library/232527/Engelbrecht.pdf .

Gerard, Albert. African Language Literatures: an introduction to the literary history of Sub-Saharan Africa. Harlow: Longman, 1981.

Hofmeyr, Isabel. The Portable Bunyan: a transnational history of 'The Pilgrim's Progress'. Princeton: Princeton University Press, 2003.

Jacquemond, R. 'Translation and cultural hegemony. The case of French-Arabic translation'. Rethinking translation. Ed. L. Venuti. London: Routledge, 1992, 139-158.

Kallaway, Peter (ed.). The history of education under apartheid, 1948-1994. Cape Town: Macmillan, 2002.

McLeod, Bruce. The Geography of Empire in English Literature 1580-1745.

Cambridge: Cambridge University Press, 1999.

\section{https://repository.uwc.ac.za/}


Mpe, Phaswane and M. Seeber. 'The Politics of Book Publishing in South Africa: A Critical Overview'. The Politics of Publishing in South Africa. Eds N. Evans and M. Seeber (eds). London: Holger Ehling Publishing, 2000, 3- 12.

Niranjana, Tejeswini. Siting Translation: History, Post-structuralism and the Colonial Context. Berkeley: University of California Press,1992.

Ntuli, Deuteronomy Bhekinkosi. Personal Communication. Pretoria: 15 July 2006.

Robinson, Douglas. Becoming a translator: an introduction to the theory and practice of translation. London: Routledge, 1999.

Robinson, Douglas. Translation and empire. Postcolonial theories explained. Manchester: St Jerome Publishers, 1997.

Schwartz, Bill. 'The Romance of the Veld'. The Round Table. The Empire, Commonwealth and British Foreign Policy. Ed. A. Bosco and A. May. London: Lothian Press, 1997: 65- 123.

Spivak, Gayatri. ‘The Politics of Translation'. The Translation Studies Reader. Ed. L. Venuti. London: Routledge, 2000, 397-416.

Venuti, Lawrence. The Translators Invisibility. A History of Translation. London: Routledge, 1995.

Vicente, Rafael. 'Translation in Wartime'. Public Culture 19:2, 2007: 239 - 246.

Wa Thiong'o, Ngugi. Decolonising the Mind: The Politics of Language and Literature in Africa. London: James Curry, 1986. 